Valóságos könyvtár - könyvtári valóság. Könyvtár- és információtudományi tanulmányok 2018. Szerk. Kiszl Péter, Csík Tibor.

Budapest, ELTE BTK Könyvtár- és Információtudományi Intézet. 2018. 155-165.

\title{
A DIGITÁLIS IRODALMI AKADÉMIA ELSŐ KÉT ÉVTIZEDE
}

\section{TÓSZEGI ZSUZSANNA}

ELTE BTK KITI, címzetes egyetemi docens

\section{TARTALMI ÖSSZEFOGLALÓ}

Húsz éve, 1997 novemberében merült föl a javaslat a Digitális Irodalmi Akadémia (DIA) megalapítására. Tudomásunk szerint a DIA a világon egyedülálló a tekintetben, hogy az akadémiai tagok szerzói jogi védelem alatt álló, teljes életművét teszi közzé az interneten, a nagyközönség számára szabad hozzáférést biztosítva a művekhez. A szerzői jogdíjat a kezdetektől fogva kormányzati támogatásból fedezik.

A DIA szolgáltatás szervezése a Petőfi Irodalmi Múzeum (PIM) és a Neumann János Digitális Könyvtár együttműködésében indult 1998 tavaszán; a honlap 2000. május 31-étől vált elérhetővé. 2006-tól a programot teljes egészében a PIM gondozza. 2017 őszén - az újonnan választott egy élő és két posztumusz taggal együtt - a DIA-nak 30 élő, és 58 időközben elhunyt, vagy posztumuszként választott tagja van. A DIA adatbázisban jelenleg 416000 oldalnyi szöveg férhető hozzá, az éves látogatottsága 650 000-680 000 körül stabilizálódott.

A DIA tanulságai több szempontból is érdekesek: a szövegfeldolgozás folyamán alkalmazott módszerek, a digitalizáláshoz kiválasztott szabványok, a szerzői jogi szabályok értelmezése és alkalmazása, a szolgáltatás összetettsége és sajátosságai - mind-mind érdemes a szakmai figyelemre.

\section{A Digitális Halhatatlanok Társaságától a Digitális Irodalmi Akadémia program létrejöttéig}

Az ezeréves államiság méltó megünneplésének szervezésére hozták létre a Magyar Millenniumi Emlékbizottságot, amely 1996-2000 között több nagy projektet irányított és számos programot szervezett. Az emlékbizottság elnöki tisztségét - miniszteri biztosi rangban - Erdödy Gábor, az ismert történész töltötte be.

A millenniumi programok között szerepelt - többek között - a Magyar Irodalom Háza ${ }^{1}$ kialakítása (benne a Károlyi-palota 1996-2000 között zajló műemléki rekonstrukciója) és a Neumann Digitális Könyvtár és Multimédia Központ létrehozatala. ${ }^{2}$

A millenniumi programok részét képezték az 1848-as forradalom 150 éves évfordulójára való megemlékezések. Az eseményhez kötődött egy akkor még nagyon újszerűnek számító program, amely a magyar íróknak, költőknek a nemzeti függetlenségi törekvésekben és a polgárosodásban játszott különleges szerepvállalására reflektált. A kulturális tárca kezdeményezte a Digitális Halhatatlanok Társasága létrehozását, amelynek 


\section{TÓSZEGI ZSUZSANNA}

egyik fontos eleme a kortárs írók legjavának életmúvéből egy ingyenesen elérhető digitalizált szöveggyújtemény kialakítása.

A Digitális Halhatatlanok program létrejöttében döntő szerepet játszott az akkori múvelődési és közoktatási miniszter, Magyar Bálint, akit - saját elmondása szerint - a kormányzati pozícióba kerülése óta foglalkoztatott az a gondolat, miként lehet a kulturális tevékenységet, beleértve a minőségi irodalmat támogatni anélkül, hogy ez politikai függőséget alakítana ki. A terv megvalósításának terepéül a Magyar Irodalom Házán belül létrehozott Kortárs Irodalmi Központ ${ }^{3}$ kínálkozott, amelynek céljai között szerepelt az irodalmi élet megélénkülésének elősegítése. Az elgondolás magában foglalta 40-50 kiemelkedő jelentőségú író, költő rendszeres anyagi támogatását. Ez utóbbival kapcsolatban több kérdés is fölmerült: hogyan lehetne egy kvázi „üzleti” viszonyt kialakítani az írókkal? Mit adhatnának ők „cserébe” a támogatásért?

A közoktatást szolgáló Sulinetprogram miatt már nem volt újdonság, hogy vásárolni is lehet digitális tartalmat. Magyar Bálint úgy vélte, a tervezett kortárs irodalmi adatbázis és online szöveggyújtemény a könyvkiadók számára nem jelent valódi konkurenciát, hiszen tömegek nem fognak számítógépen többszáz oldalas könyveket olvasni (az idő tájt még nem voltak laptopok, és az e-könyv-olvasó készülékek hírből sem voltak ismeretesek). A tervezett program mellett szóló érvek közül kiemelendő: az oktatás számára nagy előnyt jelent, ha az iskolai könyvtárakban hozzá lehet férni a kortárs múvekhez, a kutatók előtt pedig egészen új lehetőségek nyílnak meg azáltal, ha a művek szövegében egy program segítségével lehet keresni.

Nagy vita folyt arról, hogyan legyenek az írók kiválasztva? Volt olyan javaslat, amelyik egy, a kiválasztással megbízott bizottság fölállítására irányult; végül azonban egy másik szempont érvényesült: 1998 tavaszán a miniszter bekérte az élő Kossuth-dijas és Babérkoszorús írók névsorát: ők lettek a Digitális Halhatatlanok program alapító tagjai (1. ábra). ${ }^{4} \mathrm{Az}$ inflálódás elkerülése érdekében a havi díj összegét a minimálbér mindenkori alakulásához kötötték.

A Nemzeti Kulturális Alap (NKA) akkori elnöke, Török András teljes erőbedobással a program mellé állt, és sokat tett annak megvalósulása érdekében. ${ }^{5}$ Egy 2009-ben készült interjúban Török András úgy nyilatkozott, hogy az ő ötlete volt a francia Akadémia mintájára létrehozandó újszerű intézmény, amelynek javaslata Magyar Bálintnak első olvasásra megtetszett. ${ }^{6}$ 


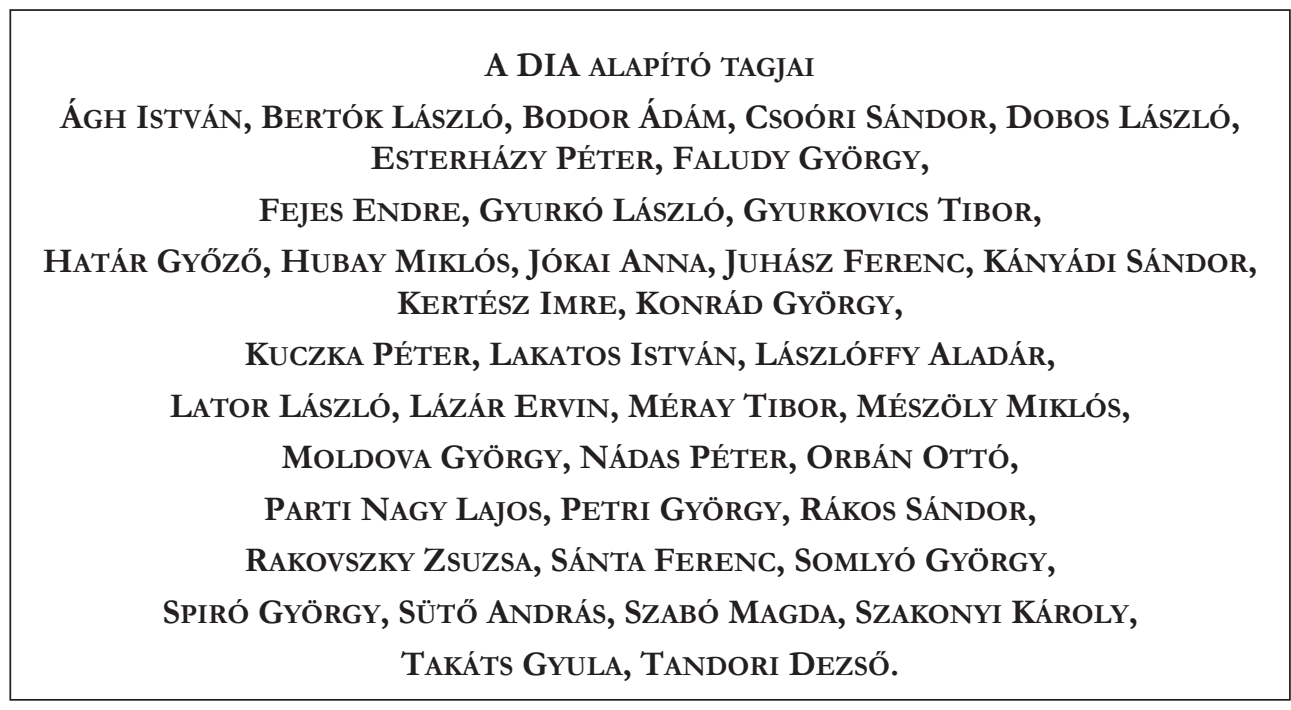

1. ábra: A DLA alapitó tagjai

A Digitális Halhatatlanok program megvalósításával a Magyar Irodalom Háza keretében működő Kortárs Irodalmi Kö̋pontot bízták meg, amelynek vezetője - főigazgató-helyettesi rangban - Magos György volt. A program megkapta a kellő kormányzati támogatást: 1998. április 6-án az NKA Bizottsága döntést hozott a program finanszírozásáról a 2000. december 31-éig terjedő időszakra vonatkozóan. Az NKA Bizottsága által jóváhagyott előterjesztésben megfogalmazták, hogy a továbbiakban a tagok teljes autonómiát élveznek a tekintetben, hogy - testületi döntés alapján - kit választanak maguk közé új tagnak. ${ }^{7}$

Az NKA-hoz benyújtott pályázat ambiciózus terveket fogalmazott meg arról, hogyan lesz a kortárs irodalom otthona az élénk, programokkal teli Kortárs Irodalmi Központ, hogyan tudják külső források bevonásával támogatni a Digitális Halhatatlanok Társasága tagjainak életmű-kiadásait, a róluk szóló monográfiák megírását, az idegen nyelvű fordítások elkészítését és kiadását. A tervezett feladatok között szerepelt, hogy a Társaság a Magyar Irodalom Háza egyik szakmai tanácsadó testülete lesz, és hozzájárul a Ház sokszínû, színvonalas működtetéséhez. ${ }^{8}$

\section{A Digitális Halhatatlanok alakuló ülése}

A Kortárs Irodalmi Központ által az NKA-hoz benyújtott pályázat jóváhagyása után megkezdődtek a tárgyalások a Digitális Halhatatlanok leendő társaságába kerülő írókkal, költőkkel. Az érintettek valamennyien elfogadták a program által kínált feltételeket, és aláírták a digitalizált műveik internetes közzétételére szóló felhasználási szerződést.

Az 1998. június 2-án tartott alakuló ülésre a világ számos országából érkeztek a „halhatatlanok”, akik az ülésen megváltoztatták a program nevét Digitális Irodalmi Aka- 


\section{TÓsZEGI ZsUZSANNA}

démiára (DIA). Ugyanekkor szavazták meg az első öt író posztumusz taggá válását; az örököseikkel sikerült a Magyar Irodalom Házának megállapodnia a digitalizálásról. ${ }^{9}$

\section{A Digitális Irodalmi Akadémia program küldetése}

Az 1998 tavaszán bejelentett, a múködését 1998 második felében megkezdő DIA küldetése, célja az azóta eltelt két évtizedben lényegében nem változott. Az egész világon egyedülálló projekt nem kevesebbre vállalkozik, mint arra, hogy a kiemelkedó életmúvet létrehozó kortárs magyar írók és költők teljes életmúvét feldolgozza, digitalizálja és a forrásértékű szövegeket, továbbá az életmű-bibliográfiákat, a szakirodalmi jegyzékeket és az életrajzokat ingyenesen hozzáférhetôvé tegye a nagyközönség számára az interneten keresztül.

\section{A DLA program megvalósitása}

A nagyszabású program kivitelezése az alábbi három nagy feladatcsoportba szerveződött:

- irodalmi előkészítés,

- digitalizálás,

- online szolgáltatás.

A DIA Szerkesztőség a nyomtatásban megjelent szövegeket előkészítette a digitalizálásra, majd végig menedzselte a folyamatot. A Neumann-ház - mint együttműködő partner - a szabvány kiválasztásában és a digitalizálást előkészítő intellektuális feladatokban vett részt, illetve 2008-ig ellátta az online szolgáltatással kapcsolatos összes feladatot (ld. alább, a vonatkozó alfejezetben).

\section{Az irodalmi elókészítésröll ${ }^{0}$}

A szöveggondozást, továbbá az életrajzok megírását, a bibliográfiák összeállítását az érintett DIA tagok által választott, a műveiket legalaposabban ismerő szakemberekre (kritikusokra, esztétákra, irodalomtudósokra stb.) bízták. ${ }^{11}$ A DIA Szerkesztőség a szakértőkkel 1998. szeptember elején kezdte meg a közös munkát: először meghatározták a számítógépes feldolgozás elveit és szempontjait. A cél: a művek minél pontosabb szöveggel, formahűen jelenjenek meg és váljanak elérhetővé. Az irodalmi szakértők vállalták, hogy áttekintik a nyomtatásban megjelent magyar nyelvű művek szövegét, öszszevetik a különböző kiadásokat (amennyiben vannak ilyenek), kijavítják az esetlegesen előforduló hibákat, vagyis „előállítják” a későbbiekben forrásértékűnek tekinthető szövegeket. A feladat további részében egybevetik a digitalizált változatot az eredeti múvel, és - amennyiben megfelel a szigorú kritériumoknak - hitelesítik azt.

A fentieken túlmenően az irodalmi szakértőket felkérték az életrajzok megírására, a szerzői művek bibliográfiájának összeállítására, továbbá a szerzőkre, illetve a múveikre vonatkozó szakirodalmi források összegyüjtésére. 
A DIA Szerkesztőség számára óriási kihívást jelentett a pontos és hiteles adatok, utalások felkutatása, a kortárs irodalom műfaji sokszínűsége és műfajelméleti tisztázatlansága, továbbá a számítógépes feldolgozás igényelte egységesítés. Időről időre fölvetôdött az igény a kritikai kiadások iránt, de ezt a feladatot a Szerkesztôség nem vállalhatta magára: sem a kompetenciája nem terjedt ki, sem a teljesítőképessége nem volt elegendő a kritikai kiadások iránt támasztandó követelmények teljesítésére.

\section{A digitalizálás és a DIA program online szolgáltatásai ${ }^{12}$}

Az irodalmi múvek digitalizálására kiírt nyílt közbeszerzési pályázatot a Free-Soft Kft. nyerte el, amellyel a Magyar Irodalom Háza 1998. november végén kötött szerződést. A vállalkozó 1998-2001 között az alábbiakban leírt szabvány és a hozzá tartozó dokumentumtípus definícióban meghatározottak szerint digitalizálta az előkészített szövegeket. 2001-től a DIA Szerkesztőség végzi a digitalizálási tevékenységet. A korrektúrázott szövegek maximális hibahatára 1\%o, vagyis szerzői ívenként 4 hiba.

A feldolgozás alapja a múvek kötetbe szerkesztett változata. A digitalizálás során minden egyes mű (regény, vers, dráma stb.) egy-egy önálló fájlba került. A művek kötetekben rögzített rendjének pontos leképezése nem volt könnyű feladat (elég csak a verseskötetek tagolására gondolni). Az igényes megjelenítés érdekében a DIA Szerkesztôség kidolgozott egy műfaj-struktúrát, amelynek adekvát elemeit a digitalizálás elôtt hozzárendelték minden egyes műhöz.

\section{A DIA program az alábbi szolgáltatásokat nyúitja az. interneten:}

Egységes elvekre épülő, strukturált szöveggyűjtemény (a művek az első hat évben oktatási, kutatási és magáncélra letölthetők voltak, 2007 óta online olvashatók);

- az alkotók életrajza, továbbá teljességre törekedve a megjelent múveik bibliográfiája és a róluk szóló szakirodalom;

- teljes szövegú adatbázis, melyből a műveket nemcsak metaadataik, de szövegük alapján is vissza lehet keresni;

- tájékozódás a digitalizált könyvek adatai, illetve a művek keletkezésére vonatkozó információk között;

- 2000-2008 között a múveket a múfajuk alapján is lehetett keresni.

\section{A Neumann-ház szerepe a Digitális Irodalmi Akadémia programjában}

A kulturális minisztérium javaslatára a DIA program két intézmény együttműködésében valósult meg. A Kortárs Irodalmi Központ feladata volt a digitalizáláshoz szükséges anyagok teljes körű beszerzése, digitalizálásra előkészítése, az adatbázisba kerülő metaadatok meghatározása. A program informatikai alapjait a Neumann János Digitális Könyvtár és Multimédia Központ (a Neumann-ház) biztosította, amely a Kortárs Irodalmi Központtal 1998. augusztus 31-én kötött együttműködési megállapodás keretében 
kidolgozta, illetve kidolgoztatta a digitalizálási előírásokat, megtervezte, feltöltötte és üzemeltette az online szolgáltatást lehetővé tévő adatbázist és elvégezte a kezelőfelület programozását. A Neumann-ház - minden külön térítés nélkül - a program indulásától részt vett a számítógépes szövegfeldolgozáshoz, illetve a hálózati szolgáltatáshoz kapcsolódó feladatok tervezésében és megvalósításában.

A DIA állománya 2000. május 31-étől érhető el az interneten. Az ünnepélyes megnyitón az akkor 86 éves Határ Gyớzó indította el az online szolgáltatást (2. ábra).

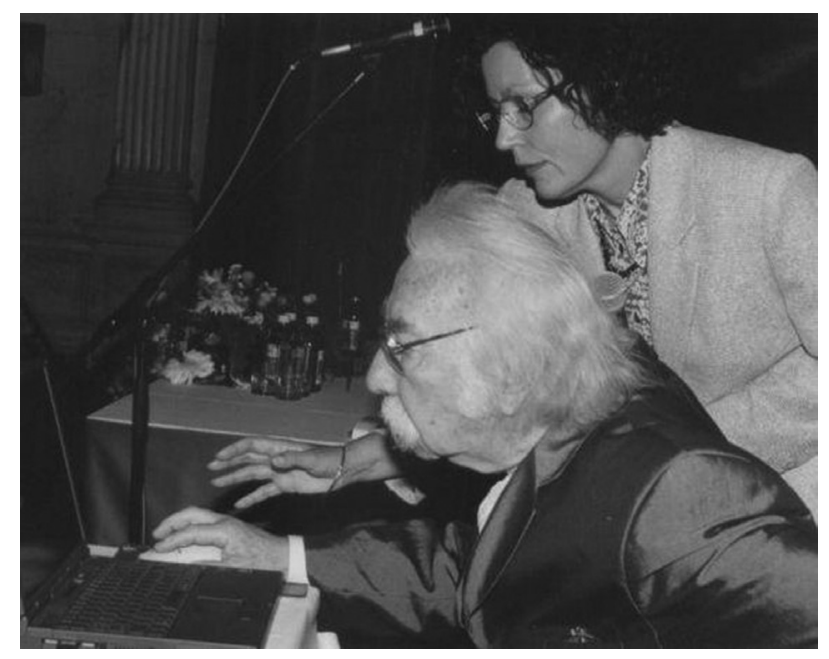

2. ábra: Határ Gyôró és a Neumann-báz vezetóje a Digitális Irodalmi Akadémia átadásán

Még abban az évben a DIA program befogadó intézménye lett a Neumann-ház: 2000. október 1-től a DIA Szerkesztőség itt folytatta munkáját 2006 végéig. A korábbi intézkedések alapján a DIA titkára a Kortárs Irodalmi Központot vezető mindenkori főigazgató-helyettes volt. Az átszervezés után Magos György a DIA Szerkesztőség vezetője lett, megtartva a DIA titkári pozícióját; e feladatokat 2006. április végéig látta el.

\section{Nemzetközi szabványok alkalmazása a szövegfeldolgozásban és a tartalomszolgáltatásban}

A Neumann-ház a megalapítása után kidolgozta a tervezett online szolgáltatások technológiai alapjait: a szövegfeldolgozásban az ISO 8879-1986 számú SGML (Standard Generalized Markup Language) szabvány alkalmazása mellett döntött. Akkor már tudni lehetett, hogy az SGML technológia bevezetése hosszú távon is kifizetődő. Az SGMLnek számos „leszármazottja” ismeretes, köztük a HTML és az XML.

Az SGML szabványos szintaktikája lehetővé teszi az ebben a formátumban tárolt dokumentumok írását, formai ellenőrzését, beolvasását. A szabványban a jelölések (tagek) jelentése nincs meghatározva, ez az alkalmazás feladata. Az SGML testre szabásához meg kell határozni a feldolgozandó állomány szintaxisát, vagyis a dokumen- 
tumtípus definícióját (DTD - Document Type Definition). A Neumann-házban 1998-ban elkészült az irodalmi múvek feldolgozására szolgáló DTD, amely az SGML-ben kódolt fájlokból sok különböző megjelenítést tett lehetővé.

Az online elérhető szöveggyűjtemények rekordjait a Neumann-ház az Oracle Library integrált könyvtári rendszerben dolgozta föl; ezzel a szoftverrel történt a Digitális Irodalmi Akadémia, a WebKat.hu, a Bibliotheca Hungarica Internetiana és a többi online szolgáltatásba kerülő rekordok metaadatainak rögzítése.

\section{A szerzói jogok kezelése}

Már a DIA gondolatának felmerülésekor megfogalmazódott, hogy a szépirodalmi alkotások internetes közzétételéért a kulturális kormányzat illő jogdijat fog fizetni. Az érintett alkotókkal a Magyar Irodalom Háza kötötte meg a felhasználási szerződéseket - első ízben az 1998. július 1-tôl 2000. december 31-ig terjedő időszakra (3. ábra).

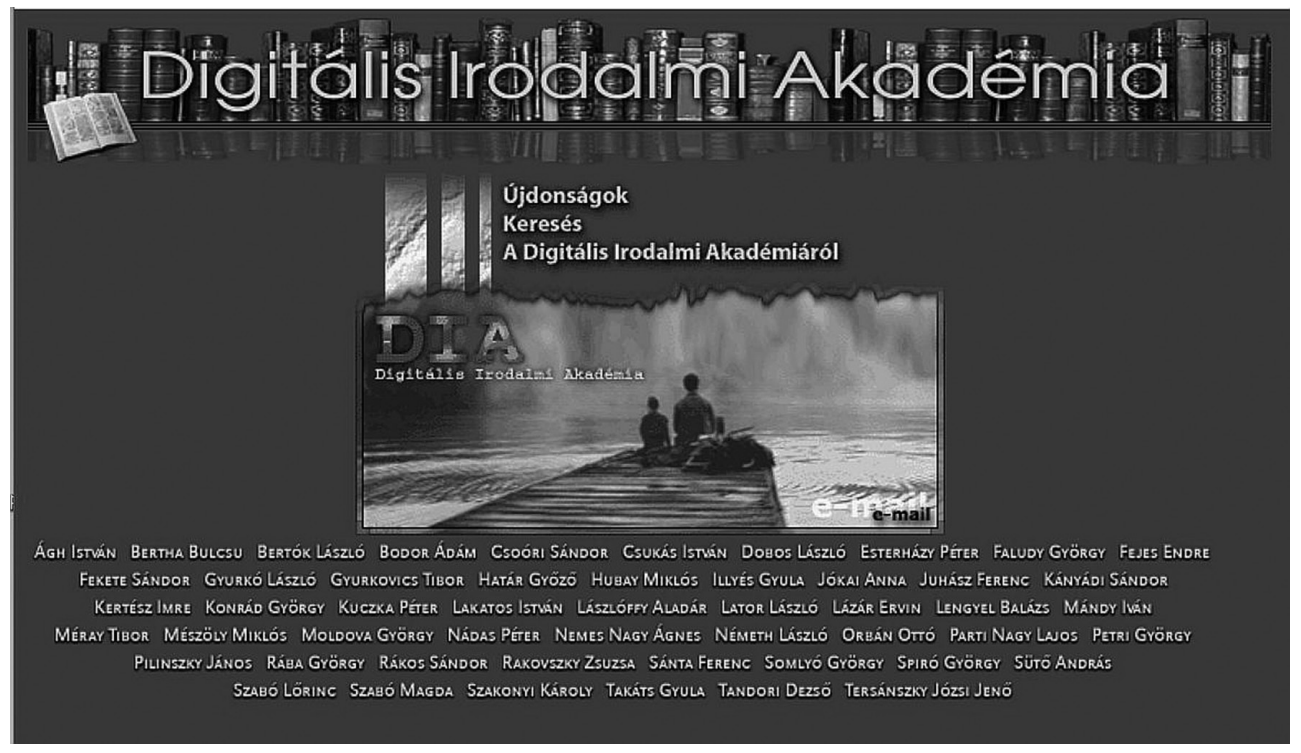

3. ábra: A DIA nyitó oldala 2000-ben

A felhasználási szerződés egyik sajátossága, hogy a DIA szolgáltatásban közzétett művek számától, terjedelmétôl független. A tagokat egyformán megillető havi díjazás jobban hasonlít az életjáradéki megállapodásokra, de a jogalapja egyértelmúen az írói életművek internetes közzétételének engedélyezése.

A DIA első ciklusában a szolgáltatási palettán szerepelt a letöltési opció. A $2007-$ ben - immár a Petőfi Irodalmi Múzeum által - újra kötött, és az alkotók egész élete során érvényes felhasználási szerződésekben a művek letöltési lehetősége (vagyis a másolatkészítés) nem szerepel. 


\section{TÓSZEGI ZSUZSANNA}

Az irodalmi Nobel-díj hatása

2002. október 10-én a DIA egyik tagja, Kertész Imre kapta meg az irodalmi Nobel-dijat. Az örömteli hír perceken belül eljutott a Neumann-házba, ahol akkor már az olvasók rendelkezésére állt Kertész Imre addig megjelent összes könyve, köztük a kitüntetett Sorstalanság című regény (4. ábra). A várhatóan nagy érdeklődés miatt - szakítva a megszokottakkal - a Nobel-díjas író könyveit néhány hónapig nemcsak a DIA adatbázisából lehetett elérni: a múvek kikerültek a Neumann-ház főoldalára.

A Nobel-díj nemcsak az alkotónak és a magyar irodalomnak hozott dicsőséget: a DIA és a Neumann-ház ismertségének és elfogadottságának is nagy szolgálatot tett. A Magvető Kiadó csak némi késéssel tudta újra kiadni a Sorstalanságot, amelyból aztán 2000 végéig 300 ezer példányt adott el. Ugyanezen idő alatt a frissen kitüntetett író műveit 155 ezren nézték meg a DIA, illetve a Neumann-ház honlapján. ${ }^{13}$

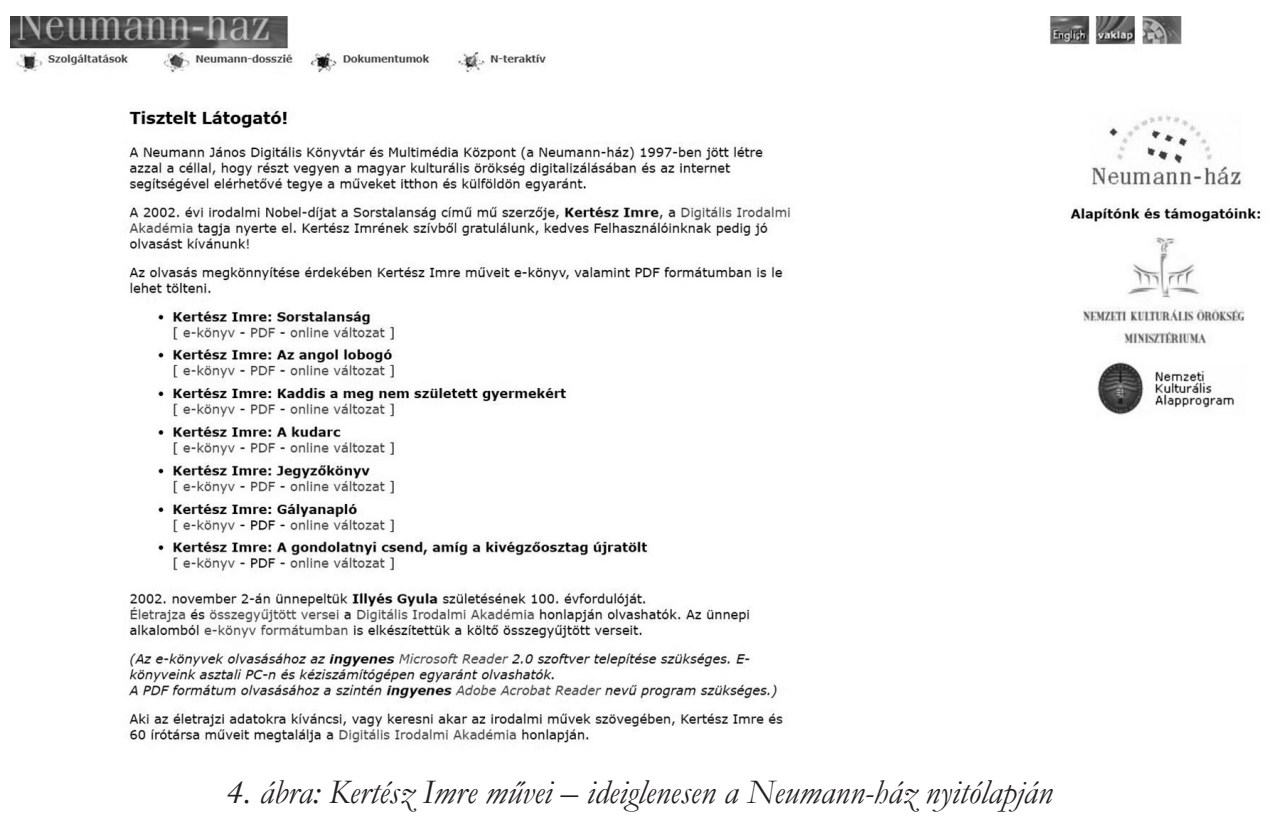

\section{A DIA program másodikéletciklusa a Petöfi Irodalmi Múzeumban (2007-töl napjainkig)}

1998 és 2006 között a DIA múködését az NKA-val évente megújított szerződések tették lehetővé -, ez a helyzet önmagában hordozta a bizonytalanságot. A fenntartó minisztérium döntése alapján 2007. január 1-tôl a DIA ismét a Petőfi Irodalmi Múzeum (PIM) szervezeti keretei közé került, és örvendetes módon kilépett az éves finanszírozású programok közül. 2007 óta a DIA a PIM költségvetésében szerepel: a múzeum élethosszig tartó felhasználási szerződéseket köthetett a DIA tagokkal.

Az együttmúködés megszúnésével a Neumann-ház átadta a PIM-nek a DIA állományában lévő szövegeket (digitalizált múveket, életrajzokat, bibliográfiákat, a mun- 
kában lévő fájlokat a dokumentációkkal együtt stb.), továbbá az adatbázisban tárolt metaadatokat. A szolgáltatás folyamatos fenntartása érdekében a Neumann-ház az új honlap megindításáig biztosította a DIA elérhetőségét.

Az irodalmi akadémia honlapja kétszer is megújult: először 2008 elején, majd 2016 tavaszán. A DIA jelenlegi adatbázisa 2009 vége óta múködik. A doménnév is változott: a www.dia.hu foglaltsága miatt a virtuális gyüjtemény korábban a www.irodalmiakademia. hu címen volt elérhető. A DIA védjegyként való bejegyeztetése és az ezen a néven múködő honlapszolgáltatás sajátosságai miatt 2008-ban sikerült a szolgáltatás számára a www.dia.hu doménnevet megkapni. A DIA tartalma a PIMMédia gyújteményében föllelhetô hanganyagokkal, fényképekkel stb. gyarapodott, de a DIA révén a múzeum is gazdagodott értékes irat- és képanyagokkal, mútárgyakkal.

Az új adatbázis és a honlap kidolgozását a DIA költségvetési keretének terhére finanszírozták 2008-ban. Az SGML formátumú fájlokat XHTML formátumúra konvertálták (5. ábra). A 2008-as adatbázis filozófiája lényegében nem tért el a korábbitól, vagyis a könyvfeldolgozás koncepciójától; az utóbbi években azonban már közelít a mú alapú megjelenítés irányába.

\section{A fák és a vének}

$\mathbf{1}$

Megvénültek, akár az őszi fák, s nincs egy levélnyi remény a tavaszra.

Indulnának, de az őszi fény padon marasztja.

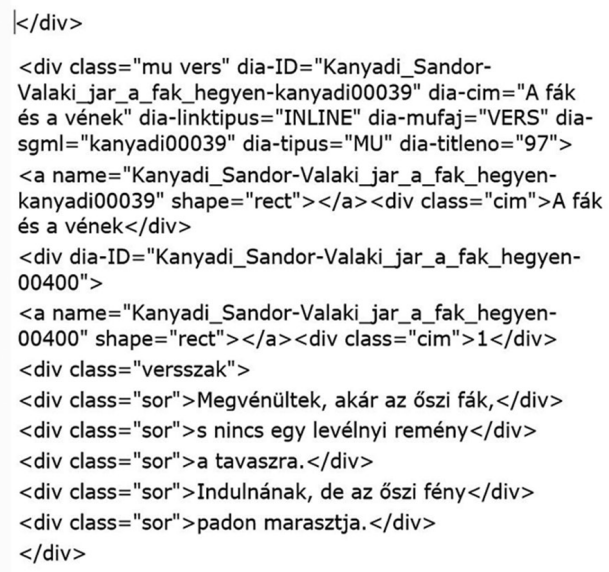

\section{5. ábra: Egy Kányádi-vers részlete a bonlapon megjelenitve és XHTML-ben}

A DIA oldalai iránt állandósulni látszik egy tisztes érdeklődés: napi átlagban 1800-an kattintanak rá a honlapra. A szolgáltatás indulásakor éves átlagban 500 ezer belépést regisztráltak, a látogatók éves átlagszáma az utóbbi időkben 650-680 ezer körül jár.

Az utóbbi években a honlap számos új elemmel gazdagodott: olvashatók új hírek a DIA tagokról, a Napi idézet minden napra új olvasnivalót kínál, elkészült az Androidos alkalmazás és a Facebook-oldal (6. ábra). 
TOVÁBB \\ IRODALMI SZAKÉRTŐK \\ ARCKÉPCSARNOK \\ FOTÓGALÉRIA \\ GYERMEKKÖNYVTÁR \\ ÉVFORDULÓK \\ DIA OLVASÓ ANDROIDRA \\ ÚJ MEGJELENÉSEK \\ ARANY 200 \\ Keresés a DIA-n \\ ÖSSZETETT KERESÉS
}

6. ábra: Napi idézet - 2018. január 30.

A huszadik születésnap évében a PIM célul tűzte ki a szövegek új adatbázisba töltését, a keresési lehetőségek bővítését - például a műfajokra is kiterjesztve -, és keresi a megoldást a DIA jogi státuszának egyértelmúbbé tételére.

$* * *$

Az alapítás óta eltelt két évtized summázata: a Digitális Irodalmi Akadémia jó példa egy újtípusú állami mecenatúrára, amely elismeri és megbecsüli a DIA tagságát, hozzájárulva alkotói szabadságuk anyagi alapjainak megteremtéséhez, ezáltal lehetővé téve új múvek megszületését.

\section{Jegyzetek és felhasznált irodalom}

A szerző itt mond köszönetet Radics Péternek, a DIA Szerkesztőség vezetőjének, akinek az önzetlen segítsége nélkül ez a dolgozat csak komoly hiányosságokkal készülhetett volna el.

1. Az 1954-ben alapított Petőfi Irodalmi Múzeum 1998. január 1-je és 1998 decembere között Magyar Irodalom Háza néven múködött, két intézményt: a Magyar Irodalmi Múzeumot és a Kortárs Irodalmi Központot magába foglalva. 1998 decemberétől Petőfi Irodalmi Múzeum és Kortárs Irodalmi Központ néven folytatta munkáját, majd ez utóbbi 2000. évi megszűnése után a Károlyi Palota Kulturális Központ része lett. 2003-tól ismét önálló intézményként, Petőfi Irodalmi Múzeum néven múködik. Forrás: Múzeumtörténet. https:// pim.hu/hu/muzeum/rolunk/muzeumtortenet [2018. július 27.] 
2. A Neumann János Digitális Könyvtár és Multimédia Központ létrehozásáról az 1997. évi CXL. sz. törvény a kulturális javak védelméről, a muzeális intézményekről, a nyilvános könyvtári ellátásról és a közművelődésről intézkedett.

3. A Kortárs Irodalmi Központ 1998. január 1. és 2000. szeptember 30. között a Magyar Irodalom Háza, illetve a Petőfi Irodalmi Múzeum szervezeti keretei között múködött. A Nemzeti Kulturális Örökség Minisztériuma miniszteri értekezletének határozata alapján 2000. október 1. hatállyal a DIA program - a szerkesztőséggel együtt - a Neumann János Digitális Könyvtár szervezeti keretei közé került.

4. A Digitális Irodalmi Akadémia megalakításáról. Interjú Magyar Bálinttal. 2018. január 10. [Hangfelvétel.] Petőfi Irodalmi Múzeum

5. 1997 őszén Török András, az NKA elnöke fölhívta telefonon e sorok íróját, az akkor létrehozott Neumann János Digitális Könyvtár és Multimédia Központ frissen kinevezett igazgatóját, azt kérve tőle, hogy készítsen el mihamarabb egy tervezetet a leendő kortárs digitális szöveggyújtemény és irodalmi adatbázis online szolgáltatásának kialakításáról. Húsz év távlatából talán nem túlzás úgy értékelni, hogy a Neumann-ház kislétszámú gárdája sikerrel teljesítette a hatalmas szakmai kihívást jelentő feladatot: megvalósította a Digitális Irodalmi Akadémia online szolgáltatását.

6. Interjú Török Andrással a DIA létrejöttéről. https://pim.hu/hu/digitalis-irodalmi- akademia/ torok-andras-interju [2018. július 27.]

7. MAGOS György: Tájékoztató a Digitális Irodalmi Akadémiáról. = Hungarológia, 1-2. sz. 2000. 119-132. p.

8. Pályázat a Digitális Halhatatlanok Program megvalósítására. Budapest, 1998. [kézirat] Petőfi Irodalmi Múzeum Digitális Irodalmi Akadémia Szerkesztősége, irattár.

9. Az 1998-ban megválasztott posztumusz tagok: Illyés Gyula, Mándy Iván, Nemes Nagy Ágnes, Németh László, Szabó Lốrinc.

10. MAGOS György, i. m.

11. Az irodalmi szakértők névsora és életrajza megtalálható a DIA honlapján: https://pim.hu/hu/ dia/irodalmi-szakertok

12. TÓSZEGI Zsuzsanna: A hazai digitális könyvtárak szerepe a kulturális örökség digitalizálásában és hozzáférhetővé tételében. = Tudományos és Műszaki Tájékoztatás, 49. évf. 4. sz. 2002. 143-148. p.

13. A következő cikk érdekes adatokat közöl a látogatók számának alakulásáról: TÓSZEGI Zsuzsanna - KORA András: Az irodalmi Nobel-díj hatása a Neumann János Digitális Könyvtár életére. = Tudományos és Műszaki Tájékoztatás, 50. évf. 3. sz. 2003. 95-99. p.

Tószegi Zsuzsanna az 1990-es évektől óraadóként oktat az Eötvös Loránd Tudományegyetem (informatikus) könyvtáros szakán, illetve a doktori programban. 2006-2015 között főiskolai, majd egyetemi docens a Kaposvári Egyetem Pedagógiai Karán. 2016-tól az ELTE BTK Könyvtár- és Információtudományi Intézetének címzetes egyetemi docense, a Könyvtártudományi Doktori Program témavezetője. 